\title{
Air Quality Index Pattern around Petroleum Production Facilities
}

\author{
J.A. Sonibare ${ }^{1 \dagger}$, F.M. Adebiyi ${ }^{2}$, E.O. Obanijesu ${ }^{3}$, and O.A. Okelana ${ }^{3}$ \\ ${ }^{1}$ Environmental Engineering Research Laboratory \\ Department of Chemical Engineering, \\ Obafemi Awolowo University, Ile-Ife, Nigeria \\ ${ }^{2}$ Environmental Pollution Research Laboratory \\ Department of Chemistry \\ Obafemi Awolowo University, Ile-Ife, Nigeria \\ ${ }^{3}$ Department of Chemical Engineering, \\ Ladoke Akintola University of Technology Ogbomoso, Nigeria
}

\begin{abstract}
In the field of air pollution control, several techniques are well established for air quality assessment. This study uses the air quality index approach to investigate the quality of air around six petroleum flow stations in the Niger Delta. The mean measured daily concentrations of both carbon monoxide $(\mathrm{CO})$ and nitrogen dioxide $\left(\mathrm{NO}_{2}\right)$ between distances 50 and $500 \mathrm{~m}$ of the flow stations were of the range $140-3400 \mu \mathrm{g} / \mathrm{m}^{3}$ and $23-1250 \mu \mathrm{g} / \mathrm{m}^{3}$ respectively. The Air quality index (AQI) from measured CO concentrations in the study area range between 1 and 44 which indicate good AQI category with no known health effects or a need for cautionary statement. Similarly, over $97 \%$ of the measured concentrations of $\mathrm{NO}_{2}$ are below $0.60 \mathrm{ppm}$. This implies that the AQI of the host environment of the Flow Stations are below 200 with respect to $\mathrm{NO}_{2}$ thus indicating a good category of air with no health alarm. However at the $60 \mathrm{~m}$ distance around a flow station, the AQI is 210 thus the available air quality at this point can be described as very unhealthy and people with respiratory or heart disease, the elderly and children are the groups most at risk. There can be significant aggravation of heart or lung disease and premature mortality in these groups of persons while significant increase in respiratory effects in general population can also be experienced. At this distance around such flow station, people with respiratory or heart disease, the elderly and children should be prevented in the morning.
\end{abstract}

Key words: Air quality Index, carbon monoxide, nitrogen dioxide, crude oil flow station

\footnotetext{
†Corresponding author: asonibar@oauife.edu.ng; asonibar@yahoo.com $+234-08033837896$
} 


\section{Introduction}

Air quality index (AQI) has proven its potential to better inform the public about air quality. It is an index for reporting daily air quality and it indicates how clean or polluted an airshed is with the possible associated health effects that might be a concern. Health effects that can be experienced within a few hours or days after breathing polluted air is its focus and with it, the number of unhealthy air days can be determined for sensitive groups (US DOT, 2005). It is established for six common air pollutants (particulate matter, carbon monoxide, sulphur dioxide, ozone and nitrogen dioxide) for which there is evidence of adverse effects of health and the environment (Abelsohn et al, 2002) and has been found to be a useful communication tools in translating technical air pollution information into information that the public can understand and use (WHO, 2006). Whenever critical air quality issues are to be discussed, air quality index has been found to be a very useful tool (IAAB, 2004). Mayer et al (2008) used it to analyze the evolution of air pollution in a space of two decades for SW Germany, Murena (2004) used it for Naples in Italy, Kyrkillis et al (2007) used for Athens, Grece while Malek et al (2006) used to study the worst national air pollution episodes in the US, among several authors. According to World Bank (1999), it does not only indicate the period of danger but in addition, it informs on what contingency plans to be implemented at occasions of very high index. Table 1 summarizes the various classes of air quality index while the possible health implications are reported in Table 2.

Table 1: Air Quality Index Classification

\begin{tabular}{|l|l|l|}
\hline Air Quality Index (AQI) Values & Levels of Health Concern & Colours \\
\hline When AQI is in the range of: & $\ldots$ air quality conditions are: & ... as symbolized by this colour: \\
\hline 0 to 50 & Good & Green \\
\hline 51 to 100 & Moderate & Yellow \\
\hline 101 to 150 & Unhealthy for Sensitive Groups & Orange \\
\hline 151 to 200 & Unhealthy & Red \\
\hline 201 to 300 & Very Unhealthy & Purple \\
\hline 301 to 500 & Hazardous & Maroon \\
\hline
\end{tabular}

Source: EPA (1999)

Table 2: Comparison of Air Quality Index with Health Effects

\begin{tabular}{|c|c|c|}
\hline Index Value & General Health Effects & Cautionary Statements \\
\hline 500 & $\begin{array}{l}\text { Premature death of ill and elderly. } \\
\text { Healthy people will experience adverse } \\
\text { symptoms that affect their normal activity }\end{array}$ & $\begin{array}{l}\text { All persons should remain indoors, } \\
\text { keeping windows and doors closed. All } \\
\text { persons should minimize physical } \\
\text { exertion and avoid source }\end{array}$ \\
\hline 400 & $\begin{array}{l}\text { Premature onset of certain diseases in } \\
\text { addition to significant aggravation of } \\
\text { symptoms and decreased exercise } \\
\text { tolerance in healthy persons }\end{array}$ & $\begin{array}{l}\text { Elderly and persons with existing diseases } \\
\text { should stay indoors and avoid physical } \\
\text { exertion. General populations should } \\
\text { avoid outdoor activity }\end{array}$ \\
\hline 300 & $\begin{array}{l}\text { Significant aggravation of symptoms and } \\
\text { decreased exercise tolerance in persons } \\
\text { with heart or lung disease, with } \\
\text { widespread symptoms in healthy } \\
\text { population }\end{array}$ & $\begin{array}{l}\text { Elderly and persons with existing heart or } \\
\text { lung disease should stay indoors and } \\
\text { reduce physical activities. }\end{array}$ \\
\hline 200 & $\begin{array}{l}\text { Mild aggravation of symptoms in } \\
\text { susceptible persons with irritation } \\
\text { symptoms in the healthy population }\end{array}$ & $\begin{array}{l}\text { persons with existing heart or respiratory } \\
\text { ailments should reduce physical exertion } \\
\text { and outdoor activity. }\end{array}$ \\
\hline 100 & - & - \\
\hline 50 & & - \\
\hline
\end{tabular}

Jacko and Breche (2003) 
Air pollution is becoming a major challenge in many tropical countries partly due to their fast rate of industrialization/urbanization which outpaces the urban planning processes. This problem also exists in the Niger Delta of Nigeria through emissions from various petroleum exploration and exploitation which involve crude oil production, transportation, refineries and further processing (Obioh et al, 1992; Baumbach et al, 1995). Presently, there is a rising concern about air pollution in the Niger Delta region (Figure 1) resulting from gas flaring and venting during upstream petroleum operation in the region (Sonibare et al, 2005; Obanijesu et al, 2009).

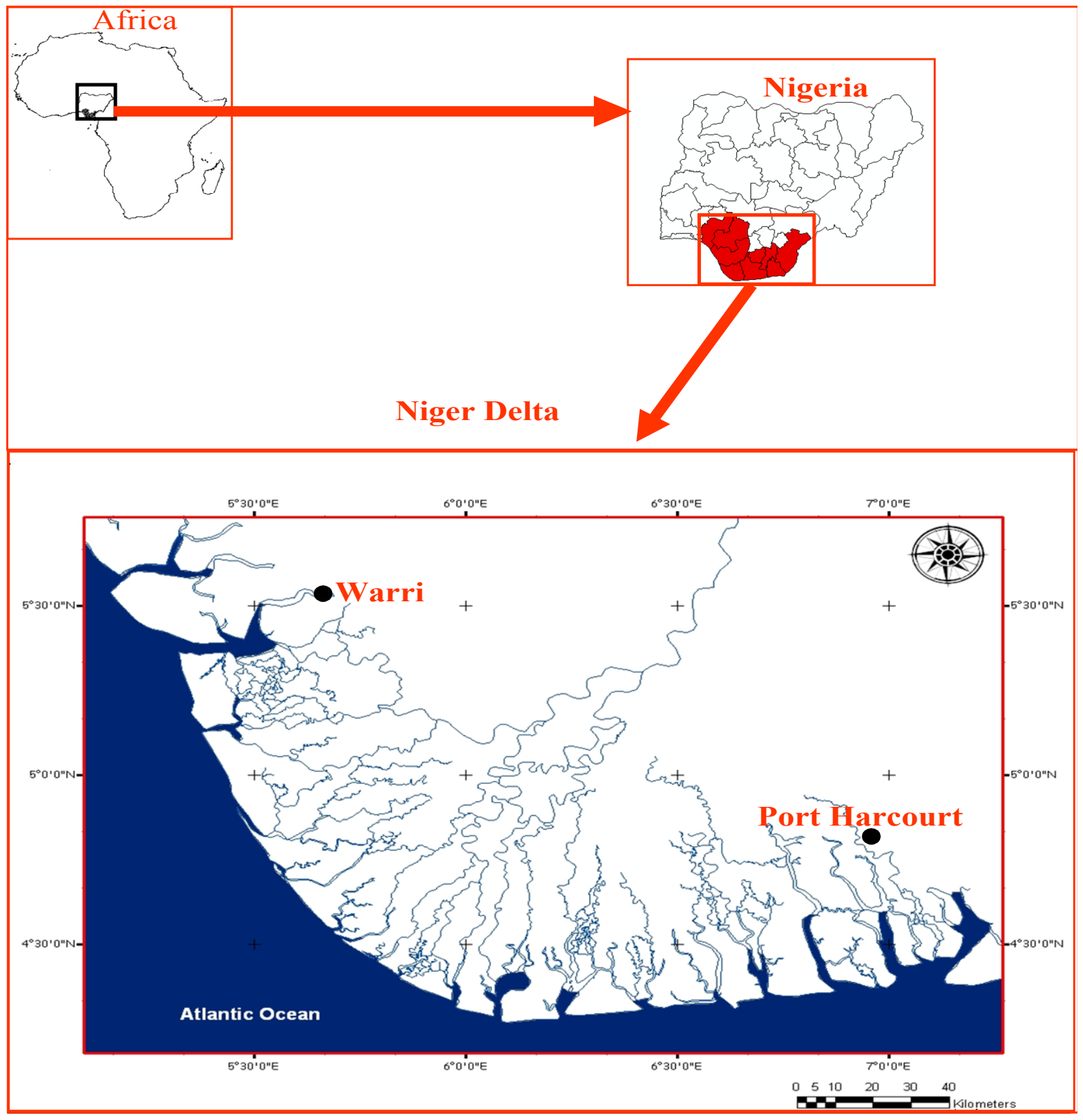

Figure 1: Niger Delta, Nigeria (Godstime, 2008)

The Niger Delta region of Nigeria accounts for $7.5 \%$ of the country's total land mass, covering about $70,000 \mathrm{~km}^{2}$ wetlands, which is the largest Wetlands in Africa (Ofeibea, 2008). It houses about 20 million people (about $14.2 \%$ of the nation's population) majority of who are subsistent farmers and fishermen. The area, sitting on over 31.4 billion barrels ultimate reserve of crude oil (Erinne, 1999) with over fourteen major Exploration and 
Production (E\&P) industries. However, the natural gas associated with the exploited crude oil is either flared or vented into the atmosphere (Obanijesu et al, 2009). Nigeria is presently the leading gas flaring country in the world, with around 24 billion cubic meters of gas flared in 2004 for instance, or 45 percent of its total gas production (World Bank, 2008) and all these take place in the Niger Delta. The gas flares which could be vertical, horizontal or angular have been identified as major sources of criteria air pollutants (Sonibare and Akeeredolu, 2004) with some releasing heavy smokes (Figure 2).

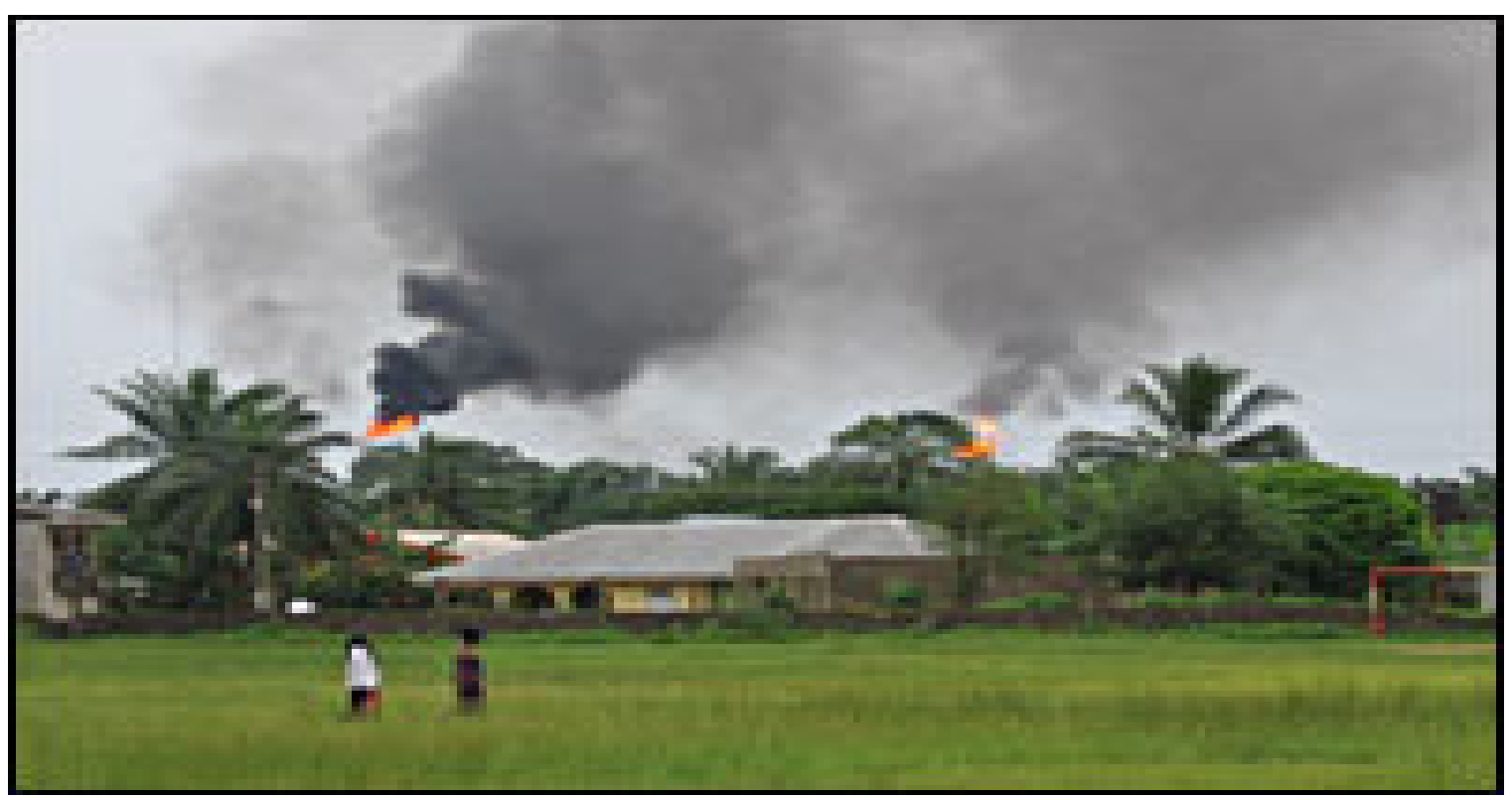

Figure 2: A Flaring Scene at Niger-Delta Region of Nigeria

Human exposure to the criteria air pollutants may lead to a variety of health problems ranging from cancer to death. In oil and gas exploration and production, Villasenor et al (2003) identified emitters of air pollutants to include: trans-shipment stations, maritime floating port terminal, drilling platforms, crude oil recovering platforms, crude oil production platforms, linking platforms, water injection platforms, pumping platforms, shelter platforms, telecommunication platforms, crude oil measurement platforms, and flaring platforms. Scheren et al (2002) and Alemagi (2007) identified gas flaring as a major emitter in the region under investigation.

At flowstations, $\mathrm{CO}$ and $\mathrm{NO}_{2}$ can be produced from flaring and other combustion activities. A mixture of $\mathrm{NO}_{2}$ and nitric oxide (NO) are emitted during combustion processes with the largest part being NO (Hofele et al, 1996). However NO produced in the combustion is subsequently oxidized to $\mathrm{NO}_{2}$ in the atmosphere (Duffy et al, 2006). Three reaction mechanisms known for the formation of oxides of nitrogen include thermal, prompt, or fuel. In thermal formation, oxides of nitrogen are formed during combustion by reaction of molecular nitrogen with oxygen when there is an excess of oxygen and a temperature above $1300{ }^{\circ} \mathrm{C}$. The prompt formation includes combustion by reaction of molecular nitrogen with fuel radicals when there is deficiency of oxygen and a temperature of $1500-2000{ }^{\circ} \mathrm{C}$. The fuel oxides of nitrogen are formed from nitrogen contained in the fuel. If present in the materials involved in combustion, ammonia forms nitrogen oxides (Abashar, 2002). $\mathrm{NO}_{2}$ is thought to have acute and chronic effects on airway and lung function, particularly in people with asthma. It is known to be radiative and chemically active with significant contribution to the greenhouse effect and main component of acid rain. The easiest way to reduce nitrogen oxides is to prevent them from forming in the first place Pereira (1999). 
Incomplete combustion of hydrocarbons at the flow stations can result in the emission of CO. According to Sonibare (2004), this can be as a result of formyl reactions where CHO radical is either broken down in presence of external agent or react with $\mathrm{H}, \mathrm{O}$, or $\mathrm{OH}$ radicals. In addition to this are: the methylene reactions where $\mathrm{CH}_{2}$ radical reacts with $\mathrm{H}, \mathrm{O}, \mathrm{OH}$, or $\mathrm{CH}_{2}$ radicals to produce $\mathrm{CO}$ as a product; sensitization of the oxidation of hydrocarbons to $\mathrm{CO}$ by $\mathrm{NO}_{\mathrm{X}}$ among other products; and the reactions of acetylene, ketyl, cyanoxy and isocyanic to produce $\mathrm{CO}$. Carbon monoxide $(\mathrm{CO})$ emissions may contribute to the formation of tropospheric ozone $\left(\mathrm{O}_{3}\right)$ which may be very harmful to human health and vegetation (NEGTAP, 2001; EPA, 2006). Excessive exposure to CO can result in human tissue being deprived of $\mathrm{O}_{2}$ and this can lead to death at certain concentration particularly for people suffering from heart diseases (Ademoroti, 1996; OSHA, 2002). CO reduction has been a global focus for decades (Goodwin et al, 2000).

In this study, the AQI patterns around some petroleum flowstations in the Niger Delta region of Nigeria are investigated using carbon monoxide $(\mathrm{CO})$ and nitrogen dioxide $\left(\mathrm{NO}_{2}\right)$ as indicators. It is expected to broaden the existing databases on Nigeria's Niger Delta airshed as a result of activities involved in her crude oil production.

\section{$2 \quad$ Methodology}

Six flow stations situated at Niger-Delta area, Nigeria are monitored daily for four consecutive months in this study. Flow station 1 is an offshore station, mounted on a concrete barge in a swamp and salt-water region. It produces about 45000 barrels per day (bpd), designed to be unmanned but has provision for accommodation with a houseboat as a support. Flow station 2 is a sand-filled three-process train facility with production capacity of about 135000 bpd. Flow station 3 is a double bank station with a design capacity of about $80000 \mathrm{bpd}$. Flow station 4 produces $30000 \mathrm{bpd}$ stabilized crude along with produced water to a terminal located $3 \mathrm{~km}$ away via a 12 delivery line. Flow station 5 is a three-bank flow station with each having $45000 \mathrm{bpd}$ capacities. It is supported on piled structure with a single deck and built on a piled area of about $50 \mathrm{~m}$ by $100 \mathrm{~m}$. Flow Station 6 is located at about 65 $\mathrm{km}$ southwest in the swamp and salt-water region of an urban center. It serves 17 hydrocarbon bearing reservoirs and 21 producing wells.

A Testo 350 Flue Gas Analyzer Model ... with a detection range of $0-5000 \mu \mathrm{g} / \mathrm{m}^{3}$ and 1 $\mu \mathrm{g} / \mathrm{m}^{3}$ resolution is used to monitor the ambient levels of both nitrogen dioxide and carbon monoxide at distances 60,200 and $500 \mathrm{~m}$ of the flow stations. Its control unit which is a portable measuring instrument for spot checks and measurements on site is equipped with a probe socket and an integrated differential pressure probe. This comprehensive range of probes makes it possible for accurate measurement of temperature, pressure, humidity, velocity, current and voltage. Air sample continuously extracted from the atmosphere is sent to the analyzer to determine the pollutant of interest.

To determine the AQI pattern, it is calculated using the EPA (1999) method with the guiding equation given in Equation (1):

Where:

$$
I_{p}=\frac{I_{H i}-I_{L o}}{B P_{H I}-B P_{L o}}\left(C_{P}-B P_{L o}\right)+I_{L o}
$$

$\mathrm{I}_{\mathrm{P}}=$ the index value of pollutant $\mathrm{p}$

$\mathrm{C}_{\mathrm{P}}=$ the truncated concentration of pollutant $\mathrm{p}$

$\mathrm{BP}_{\mathrm{HI}}=$ the breakpoint that is greater than or equal to $\mathrm{C}_{\mathrm{P}}$ as given in Table 3 
$\mathrm{BP}_{\mathrm{Lo}}=$ the breakpoint that is less than or equal to $\mathrm{C}_{\mathrm{P}}$ as given in Table 3

$\mathrm{I}_{\mathrm{Hi}}=$ the $\mathrm{AQI}$ value corresponding to $\mathrm{BP}_{\mathrm{HI}}$

$\mathrm{I}_{\mathrm{Lo}}=$ the $\mathrm{AQI}$ value corresponding to $\mathrm{BP}_{\mathrm{Lo}}$

Table 3: Breakpoints for the Air Quality Index (AQI)*

\begin{tabular}{|c|c|c|}
\hline \multicolumn{2}{|c|}{ Breakpoints } & \multirow[t]{2}{*}{ AQI } \\
\hline $\mathrm{CO}$ (ppm) & $\mathrm{NO}_{2}(\mathrm{ppm})$ & \\
\hline $0.0-4.4$ & \multirow{4}{*}{ Not applicable } & $0-50$ \\
\hline $4.5-9.4$ & & $51-100$ \\
\hline $9.5-12.4$ & & $101-150$ \\
\hline $12.5-15.4$ & & $151-200$ \\
\hline $15.5-30.4$ & $0.65-1.24$ & $201-300$ \\
\hline $30.5-40.4$ & $1.25-1.64$ & $301-400$ \\
\hline $40.5-50.4$ & $1.65-2.04$ & $401-500$ \\
\hline
\end{tabular}

*Source: EPA (1999)

${ }^{a} \mathrm{NO}_{2}$ has no short-term National Ambient Air Quality Standard (NAAQS) and can generate an AQI only above an AQI of 200.

\section{Results and Discussion}

Measured ambient $\mathrm{NO}_{2}$ concentrations from the flow stations were of the range $20-1750$ $\mu \mathrm{g} / \mathrm{m}^{3}$ and $20-1450 \mu \mathrm{g} / \mathrm{m}^{3}$ for the morning-time and afternoon-time respectively with the morning mean of $23-1250 \mu \mathrm{g} / \mathrm{m}^{3}$ and afternoon mean of $38-963 \mu \mathrm{g} / \mathrm{m}^{3}$ (Table 4). These mean concentrations are greater than the $75-113 \mu \mathrm{g} / \mathrm{m}^{3}$ set limit of Nigeria's Federal Ministry of Environment (FEPA, 1991) in all but one location at the $60 \mathrm{~m}$ from the flow station, but in three of the receptor locations at both the $200 \mathrm{~m}$ and $500 \mathrm{~m}$ to the flow stations. Two other reference standards for $\mathrm{NO}_{2}$ among the operators in the Nigerian environment are both the Department of Petroleum Resources (EGASPIN, 2002) and the World Bank (World Bank, 1999). When their $\mathrm{NO}_{2}$ set limit of $150 \mu \mathrm{g} / \mathrm{m}^{3}$ is used to the determine the level of compliance at these flow stations of interest, it is observed that the mean measured levels of $\mathrm{NO}_{2}$ at the $60 \mathrm{~m}$ and the $200 \mathrm{~m}$ receptor locations comply only in two and four points respectively at the morning-time. However, at this same period of the day, the measured concentrations at the $500 \mathrm{~m}$ receptor location are within the set limit in all the flow stations.

Table 4: Concentration of $\mathrm{NO}_{2}$ in around the Studied Flow Stations

\begin{tabular}{|l|l|l|l|l|l|l|}
\hline \multirow{2}{*}{$\begin{array}{l}\text { Flow } \\
\text { Station }\end{array}$} & \multicolumn{5}{|c|}{ Concentration $\left(\mu \mathrm{g} / \mathrm{m}^{3}\right)$} \\
\cline { 2 - 7 } & \multicolumn{1}{|c|}{ Distance (Morning Sampling Period) } & \multicolumn{1}{|c|}{ Distance (Afternoon Sampling Period) } \\
\cline { 2 - 7 } & $60 \mathrm{~m}$ & $200 \mathrm{~m}$ & $500 \mathrm{~m}$ & $60 \mathrm{~m}$ & $200 \mathrm{~m}$ & $500 \mathrm{~m}$ \\
\hline 1 & $80.0-300$ & $30.0-120$ & $40.0-100$ & $60.0-90.0$ & $40.0-120$ & $40.0-110$ \\
& $(198 \pm 90.3)$ & $(70.0 \pm 37.4)$ & $(82.5 \pm 28.7)$ & $(80.0 \pm 14.1)$ & $(80.0 \pm 46.2)$ & $(62.5 \pm 32.0)$ \\
\hline 2 & $80.0-125$ & $30.0-150$ & $40.0-150$ & $60.0-90.0$ & $40.0-120$ & $50.0-125$ \\
& $(93.8 \pm 21.4)$ & $(67.5 \pm 55.6)$ & $(70.0 \pm 53.4)$ & $(67.5 \pm 15.0)$ & $(60.0 \pm 40.0)$ & $(68.8 \pm 37.5)$ \\
\hline 3 & $20.0-100$ & $20.0-60.0$ & $20.0-30.0$ & $20.0-100$ & $20.0-70.0$ & $20.0-50.0$ \\
& $(68.8 \pm 34.2)$ & $(32.5 \pm 18.9)$ & $(22.5 \pm 5.00)$ & $(60.0 \pm 32.7)$ & $(43.0 \pm 20.6)$ & $(37.5 \pm 15.0)$ \\
\hline 4 & $60.0-155$ & $75.0-500$ & $50.0-60.0$ & $20.0-170$ & $30.0-500$ & $60.0-600$ \\
& $(104 \pm 56.5)$ & $(276 \pm 230)$ & $(53.8 \pm 4.79)$ & $(95.0 \pm 81.0)$ & $(183 \pm 241)$ & $(196 \pm 269)$ \\
\hline 5 & $50.0-1750$ & $20-140$ & $20.0-320$ & $100-1450$ & $20.0-100$ & $20.0-80.0$ \\
& $(1250 \pm 807)$ & $(55.0 \pm 56.7)$ & $(180 \pm 152)$ & $(963 \pm 593)$ & $(48.8 \pm 36.6)$ & $(50.0 \pm 31.9)$ \\
\hline 6 & $20.0-145$ & $20.0-205$ & $20.0-60.0$ & $20.0-210$ & $20.0-300$ & $20.0-110$ \\
& $(101 \pm 57.1)$ & $(156 \pm 90.9)$ & $(30.0 \pm 20.0)$ & $(145 \pm 87.4)$ & $(215 \pm 132)$ & $(77.5 \pm 40.3)$ \\
\hline
\end{tabular}


Table 5 summarizes the measured $\mathrm{CO}$ concentrations as obtained during the study. The mean concentrations are of the range $250-3400 \mu \mathrm{g} / \mathrm{m}^{3}$ in the morning and $140-3700 \mu \mathrm{g} / \mathrm{m}^{3}$ in the afternoon which are all far less than the $11400 \mu \mathrm{g} / \mathrm{m}^{3}$ daily limit of the Federal Ministry of Environment (FEPA, 1991) and $10000 \mu \mathrm{g} / \mathrm{m}^{3}$ of her Department of Petroleum Resources (EGASPIN, 2002).

Table 5: Concentration of $\mathrm{CO}$ around the Flow Stations

\begin{tabular}{|c|c|c|c|c|c|c|}
\hline \multirow{3}{*}{$\begin{array}{l}\text { Flow } \\
\text { Station }\end{array}$} & \multicolumn{6}{|c|}{ Concentration $\left(\mu \mathrm{g} / \mathrm{m}^{3}\right)$} \\
\hline & \multicolumn{3}{|c|}{ Distance (Morning Sampling Period) } & \multicolumn{3}{|c|}{ Distance (Afternoon Sampling Period) } \\
\hline & $60 \mathrm{~m}$ & $200 \mathrm{~m}$ & $500 \mathrm{~m}$ & $60 \mathrm{~m}$ & $200 \mathrm{~m}$ & $500 \mathrm{~m}$ \\
\hline 1 & $\begin{array}{l}300-2350 \\
(1800 \pm 1000)\end{array}$ & $\begin{array}{l}750-850 \\
(800 \pm 50)\end{array}$ & $\begin{array}{l}450-2750 \\
(1100 \pm 1130)\end{array}$ & $\begin{array}{l}400-3750 \\
(2800 \pm 1580)\end{array}$ & $\begin{array}{l}850-2650 \\
(2100 \pm 820)\end{array}$ & $\begin{array}{l}500-3250 \\
(1200 \pm 1380)\end{array}$ \\
\hline 2 & $\begin{array}{l}2100-2350 \\
(2300 \pm 130)\end{array}$ & $\begin{array}{l}750-850 \\
(800 \pm 50) \\
\end{array}$ & $\begin{array}{l}500-550 \\
(500 \pm 30) \\
\end{array}$ & $\begin{array}{l}3550-3850 \\
(3700 \pm 130)\end{array}$ & $\begin{array}{l}2450-2650 \\
(2600 \pm 90)\end{array}$ & $500^{*}$ \\
\hline 3 & $\begin{array}{l}980-5350 \\
(3400 \pm 2180)\end{array}$ & $\begin{array}{l}750-1370 \\
(1190 \pm 300)\end{array}$ & $\begin{array}{l}100-900 \\
(500 \pm 450)\end{array}$ & $\begin{array}{l}1150-2350 \\
(1700 \pm 700)\end{array}$ & $\begin{array}{l}190-1960 \\
(1150 \pm 750)\end{array}$ & $\begin{array}{l}100-1140 \\
(400 \pm 490)\end{array}$ \\
\hline 4 & $\begin{array}{l}630-1740 \\
(1200 \pm 610)\end{array}$ & $\begin{array}{l}300-3850 \\
(2800 \pm 1680)\end{array}$ & $\begin{array}{l}400-750 \\
(400 \pm 250)\end{array}$ & $\begin{array}{l}750-2200 \\
(1700 \pm 660)\end{array}$ & $\begin{array}{l}900-6530 \\
(4600 \pm 2650)\end{array}$ & $\begin{array}{l}450-1100 \\
(500 \pm 290)\end{array}$ \\
\hline 5 & $\begin{array}{l}2300-2350 \\
(2500 \pm 380)\end{array}$ & $\begin{array}{l}700-1100 \\
(900 \pm 220)\end{array}$ & $\begin{array}{l}100-2360 \\
(1300 \pm 1120)\end{array}$ & $\begin{array}{l}100-2140 \\
(900 \pm 890)\end{array}$ & $\begin{array}{l}750-1100 \\
(1000 \pm 180)\end{array}$ & $\begin{array}{l}100-850 \\
(500 \pm 310)\end{array}$ \\
\hline 6 & $\begin{array}{l}100-2710 \\
(800 \pm 1270)\end{array}$ & $\begin{array}{l}100-430 \\
(250 \pm 140)\end{array}$ & $\begin{array}{l}100-1710 \\
(500 \pm 540)\end{array}$ & $\begin{array}{l}100-2550 \\
(700 \pm 1230)\end{array}$ & $\begin{array}{l}100-170 \\
(140 \pm 30)\end{array}$ & $\begin{array}{l}100-1850 \\
(500 \pm 880)\end{array}$ \\
\hline
\end{tabular}

*Range and mean are the same

The frequency distribution of the overall mean concentrations of $\mathrm{NO}_{2}$ and $\mathrm{CO}$ for all the point source distances in the morning and afternoon time are as presented in Figures 3 and 4 respectively. The concentrations of both gases decrease with increase in distance from point source for both the morning and afternoon samplings viz; $60 \mathrm{~m}>200 \mathrm{~m}>500 \mathrm{~m}$, except for $\mathrm{CO}$ at $60 \mathrm{~m}$ and $200 \mathrm{~m}$ in the afternoon sampling, an indication that ambient concentrations of air pollutants depend on distance from any major point sources. Generally, the concentrations of $\mathrm{CO}$ are generally higher than $\mathrm{NO}_{2}$ in all the distances from the flow stations both in the morning and afternoon sampling periods. This might be attributed to the high carbon content of natural gas with little or no nitrogen since natural gas is high carboncontaining compound when compared to its nitrogen-containing level (Tissot and Welte, 1984). In fact the $\mathrm{NO}_{2}$ formed during combustion of natural gas might be from the conversion of nitrogen present in the combustion air rather than that present in the fuel itself.

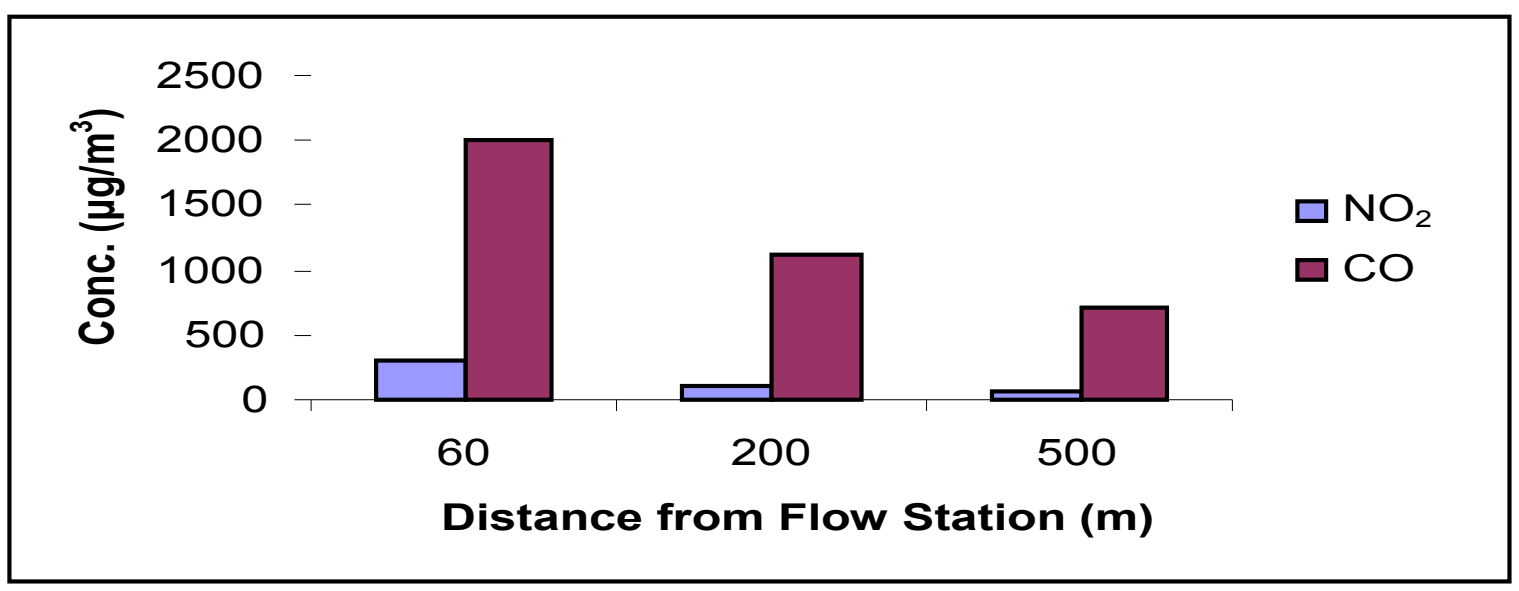

Figure 3: Frequency Distribution of the Mean Measured Concentrations (Morning) 


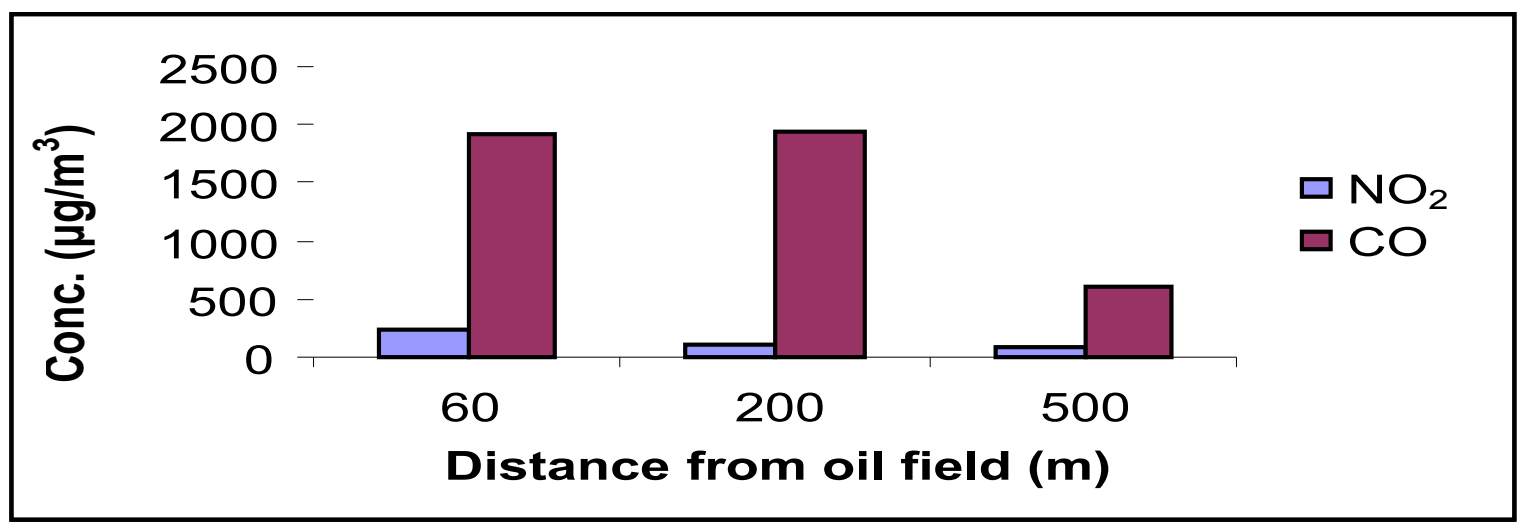

Figure 4: Frequency Distribution of the Mean Measured Concentrations (Afternoon)

As shown in Tables 1 and 2, the measured gaseous concentrations of both the $\mathrm{NO}_{2}$ and $\mathrm{CO}$ are less dependent on the time of day but possibly more on environmental parameters including both wind speed and direction. A test of significance on the relationship between measured gaseous concentrations and time of day is carried out using T-test (Table 6). The difference in the values of each parameter for the two sampling times is considered significant from statistical sense if T-test value is less than 0.05 . However, none of the calculated values is significant, confirming that concentration of these air pollutants is independent of sampling time, either morning or afternoon time.

Table 6: Comparison of Gaseous Concentrations per Distance using T-test values

\begin{tabular}{|l|c|c|c|c|c|c|}
\hline Parameter & \multicolumn{3}{|c|}{$\mathrm{NO}_{2}$} & \multicolumn{3}{c|}{$\mathrm{CO}$} \\
\hline Distance (m) & 60 & 200 & 500 & 60 & 200 & 500 \\
\hline T-test value & 0.392 & 0.464 & 0.397 & 0.447 & 0.148 & 0.284 \\
\hline
\end{tabular}

*The value is significant at T-test $<0.05$

Calculated T-test values when the levels of the $\mathrm{NO}_{2}$ are compared with $\mathrm{CO}$ levels at every distance both in the morning are reported in Table 7 . The calculated values are significant $(\mathrm{T}$ test $<0.05$ ) and this can be attributed to the higher concentrations of $\mathrm{CO}$ than that of $\mathrm{NO}_{2}$ at all the locations as earlier indicated.

Table 7: Comparison of Concentrations of $\mathrm{NO}_{2}$ versus $\mathrm{CO}$ per distance using T-test values

\begin{tabular}{|l|c|c|c|c|c|c|}
\hline Sampling time & \multicolumn{3}{|c|}{ Morning } & \multicolumn{3}{c|}{ Afternoon } \\
\hline Distance (m) & 60 & 200 & 500 & 60 & 200 & 500 \\
\hline T-test value & 0.001 & 0.009 & 0.001 & 0.003 & 0.008 & 0.0009 \\
\hline
\end{tabular}

*The value is significant at T-test $<0.05$

Correlation coefficient is considered between $\mathrm{NO}_{2}$ and $\mathrm{CO}$ partly to investigate the possibility of common source as reported in Figure 5. A very strong and positive correlation exists between the two pollutants. However, their computed $\mathrm{R}^{2}$ value of 0.6879 signifies a strong possibility of common sources chief among which are gas flaring, vehicular emissions, bush burning, and other heavy equipment used around the flow stations.

\section{Air Quality Index Implication of Measured Concentrations}

As indicated earlier, $\mathrm{NO}_{2}$ can generate $\mathrm{AQI}$ only above a value of 200 corresponding to 0.65 $-2.04 \mathrm{ppm}$. From this study, its truncated concentrations range between $0.01-0.65 \mathrm{ppm}$ measured during the morning period at distance $500 \mathrm{~m}$ from flow station 3 and during the 


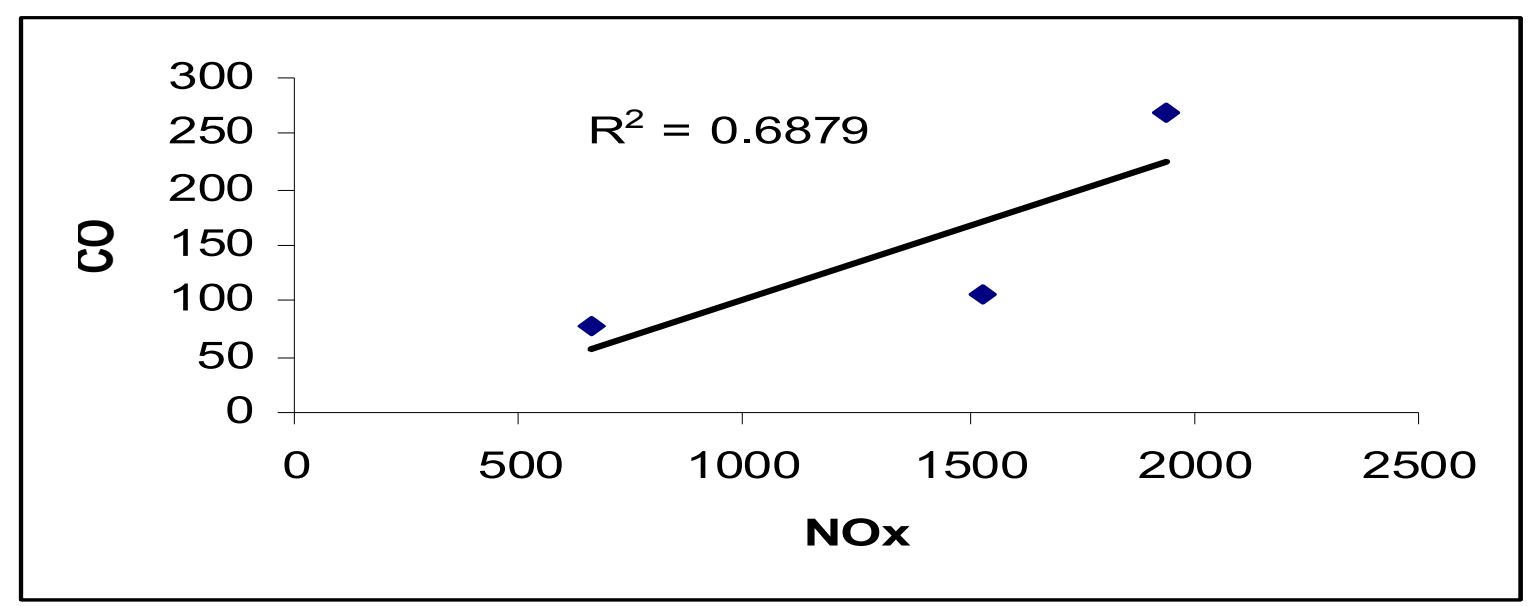

Figure 5: Plot of Correlation Coefficient between $\mathrm{CO}$ and $\mathrm{NO}_{2}$

afternoon period at distance $60 \mathrm{~m}$ from flow station 5 respectively. Except this concentration of $0.65 \mathrm{ppm}$ which is equivalent to an AQI of 210, over $97 \%$ of the measured concentrations of $\mathrm{NO}_{2}$ in the study area are below $0.60 \mathrm{ppm}$ which implies that the AQI of the host environment of the flow stations are below 200 with respect to $\mathrm{NO}_{2}$ thus indicating a good category of air with no health alarm. However at the $60 \mathrm{~m}$ distance around the flow station 5 , the available air quality can be described as very unhealthy and people with respiratory or heart disease, the elderly and children are the groups most at risk. According to EPA (1999), significant aggravation of heart or lung disease and premature mortality in persons with cardiopulmonary disease and the elderly are the health implications while significant increase in respiratory effects in general population can also be experienced. At this distance around such flow station, people with respiratory or heart disease, the elderly and children should be prevented in the morning.

The AQI from measured CO concentrations in the study area ranges between 1 and 44 (Figure 6) which indicates good AQI category with no known health effects or a need for cautionary statement. However, people with heart disease are the group most at risk (EPA, 1999).

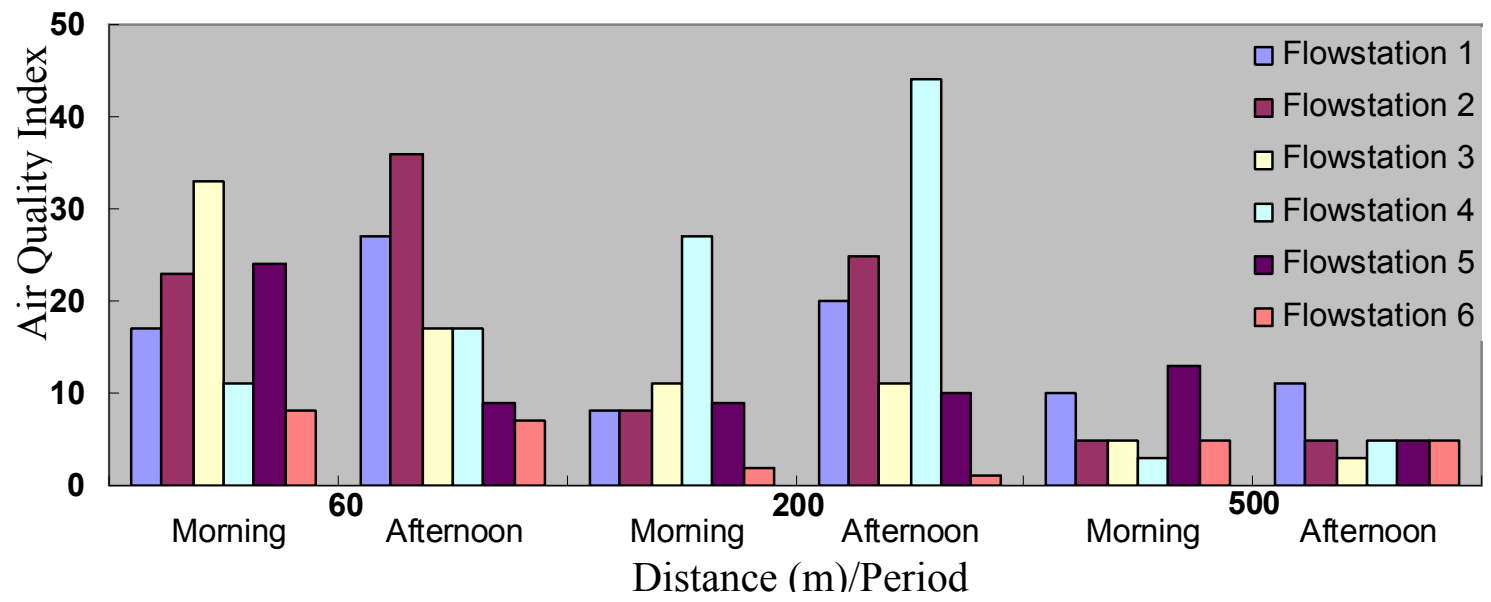

Figure 6: AQI with respect to CO around the Flow Stations 


\section{Conclusion}

The AQI from measured CO concentrations in the study area which ranges between 1 and 44 indicates good AQI category with no known health effects or a need for cautionary statement. Similarly, over $97 \%$ of the measured concentrations of $\mathrm{NO}_{2}$ are below $0.60 \mathrm{ppm}$ which implies that the AQI of the host environment of the Flow Stations are below 200 with respect to $\mathrm{NO}_{2}$ thus indicating a good category of air with no health alarm. However at the $60 \mathrm{~m}$ distance around a Flow Station, the AQI is 210 thus the available air quality at this point can be described as very unhealthy and people with respiratory or heart disease, the elderly and children are the groups most at risk. At this distance around such Flow Stations, people with respiratory or heart disease, the elderly and children should be prevented in the morning.

\section{References}

Abashar, M.E.E (2002) Integrated catalytic membrane reactors for decomposition of Ammonia. Chemical Engineering and Processing 41 (5) 403-412

Abelsohn, A., Stieb, D., Sanborn, M.D., and Weir, E. (2002) Identifying and managing adverse environmental health effects: Outdoor air pollution. Canadian Medical Association Journal 166 (9), $1161-1167$.

Ademoroti, C. M. A. (1996) Environmental Chemistry and Toxicology, 1st Edn. Ibadan, Nigeria, $30-31$

Alemagi, D. (2007) The Oil Industry along the Atlantic Coast of Cameroon: Assessing Impacts and Possible Solutions. Resources Policy Volume 32 (3), Pages 135-145.

Baumbach, G; Vogt, U; Hein, K.R.G, Oluwole, A.F; Ogunsola, O.J; Olaniyi, H.B and Akeredolu, F.A (1995). Air Pollution in a large Tropical City with a high Traffic DensityResults of Measurements in Lagos, Nigeria. The Sci. of Total Environ., 169: 25-31

Duffy, A., Walker, G.M., and Allen, S.J (2006) Investigations on the adsorption of acidic gases using activated dolomite, Chemical Engineering Journal 117 (3) 239-244

EGASPIN (2002) The Environmental Guidelines and Standards for the Petroleum Industry in Nigeria. The Department of Petroleum Resources, Lagos. Nigeria.

EPA (1999) http://airnow.gov/index.cfm?action=static.aqi Accessed on Dec. 30, 2008.

EPA. (2006) Backyard Burning- Human Health Effect, Retrieved July 7, 2007, from World Wide Web:http://www.epa.gov/garbage/backyard/health.htm

FEPA (1991) Guidelines and Standards for Environmental Pollution Control in Nigeria, 33, 103. Federal Environmental Protection Agency, Lagos.

Godstime J. (2008) Impacts of gas flaring and policy issues in the Niger Delta Region. Retrieved on November 25, 2008 from World Wide Web:

cas.umkc.edu/geo/GlobalClimateChange/StudentsProjects/Godstime.ppt 
Hofele, J., Velzen, D.V., Langenkamp, H., and Schaber, K (1996) Absorption of NO in Aqueous Solutions of $\mathrm{Fe}^{\mathrm{II}} \mathrm{NTA}$ : Determination of the Equilibrium Constant Chemical Engineering and Processing 35 (4), 295 - 300.

IAAB (2004) Summary of Critical Air Quality Issues in the Transboundary Region. Report from the International Air Quality Advisory Board to the International Joint Commission. USA. 26 pp.

Jacko, R. and Breche, T. L.A (2003) Air Pollution and Noise Control in: Salvato, J.A., Nemerow, N.L. and Agardy, F.J. (eds) Environmental Engineering, John Willey \& Sons, Inc., New Jersey. Pp. 88.

Kyrkilis, G., Chaloulakou, A., and Kassomenos, P.A (2007) Development of an aggregate Air Quality Index for an urban Mediterranean agglomeration: Relation to potential health effects. Environment International, Volume 33, Issue 5, July 2007, Pages 670-676

Malek E., Davis, T., Martin, R.S., and Silva, P.J (2006) Meteorological and Environmental Aspects of one of the Worst National Air Pollution Episodes (January, 2004) in Logan, Cache Valley, Utah, USA. Atmospheric Research 79, 108 - 122.

Mayer, H., Holst, J., Schindler, D. and Ahrens, D. (2008) Evolution of the air pollution in SW Germany evaluated by the long-term air quality index LAQx. Atmospheric Environment Volume 42, Issue 20, June 2008, Pages 5071-5078

Murena, F (2004) Measuring air quality over large urban areas: development and application of an air pollution index at the urban area of Naples. Atmospheric Environment Volume 38, Issue 36, November 2004, Pages 6195-6202

ObaniJesu, E.O., F.M. Adebiyi, J.A. Sonibare, O.A. Okelana. Air-Borne $\mathrm{SO}_{2}$ Pollution Monitoring in the Petroleum Operation Areas of Niger-Delta, Nigeria. Energy Sources Part A: Recovery, Utilization and Environmental Effects, U.S.A, 31: 223-231 (2009)

Obioh, I.B; Oluwole, A.F and Akeredolu, F.A (1992). Air pollution Investigation and Emission Estimates for Nigeria in 1988, in Intergovernmental Panel on Climate Change Workshop, Bra knell, UK, 29-30

Ofedia, Q (2008). Gas flaring disrupts life in oil-producing Niger Delta. Retrieved on November 21, 2008 from World Wide Web:

http://www.npr.org/templates/story.php?storyId=12175714

OSHA Fact Sheet (2002) Carbon Monoxide Poisoning. Occupational Safety in Health Administration, Departmental of Labor, U.S Retrieved on April 30, 2007 from World Wide Web:http://www/osha.gov/oshDoc/data/general.facts/carbonmonoxide-factsheet.pdf

Pereira, C.J (1999) Environmentally Friendly Processes. Chemical Engineering Science 54 (13-14) 1959 - 1973 
Scheren, P.A., Ibe, A.C., Janssen, F.J., and Lemmens, A.M (2002) Environmental pollution in the Gulf of Guinea - a regional approach. Marine Pollution Bulletin Volume 44 (7), July 2002, Pages 633-641

Sonibare, J.A., Obanijesu, E.O., Adebiyi, F.M., Akeredolu, F.A (2005) Potential Contribution of Volatile Organic Compounds (VOCs) to Nigeria's Airshed by Petroleum Refineries, nafta, Croatia, 56 (6)

Tissot, B. P. and Welte, D. H. (1984) Petroleum Formation and Occurrence, 2nd Edn. New York, $379-473$.

US DOT (2005) Integrating Air Quality and Transportation Plan, US Department of Transportation, USA.

Villasenor, R. Magdaleno, M., Quintanar, A., Gallardo, J.C., López, M.T., Jurado, R., Miranda, A., Aguilar, M., Melgarejo, L.A., Palmerín, E., Vallejo, C.J., and Barchet, W.R (2003) An air quality emission inventory of offshore operations for the exploration and production of petroleum by the Mexican oil industry, Atmospheric Environment Volume 37 (26), 3713-3729

WHO (2006) Air Quality Guidelines Global Update, 2005: Particulate Matter, Ozone, Nitrogen Dioxide and Sulphur Dioxide. World Health Orgranization, Regional Office for Europe, Denmark. Pp. 484

World Bank (1999) Pollution Prevention and Abatement Handbook 1998: Toward Cleaner Production. World Bank, USA.

World Bank (2008) Global Gas Flaring Reduction Partnership: Towards a World Free of Flares. www.worldbank.org/ggfr Accessed on January 5, 2009. 